\title{
Puerto Cabello: la rendición del último bastión monárquico en Venezuela durante las guerras de Independencia
}

Roger Pita Pico*

Recibido el 27 de marzo de 2019; aceptado el 24 de septiembre de 2019

\section{RESUMEN}

En el marco de la conmemoración del Bicentenario del período de Independencia de las naciones hispanoamericanas, este artículo tiene por objeto analizar el proceso de rendición de la ciudad de Puerto Cabello, último bastión del régimen monárquico en Venezuela. Tras la firma de las capitulaciones convenidas para esta plaza, se pueden identificar en términos generales varias etapas claramente definidas que serán examinadas a lo largo de este artículo: la rendición, la juramentación, la desmovilización, la entrega de armas y la reinserción. Esta vía pacífica fue, en términos reales, una opción sensata de las partes en la fase final de una guerra larga y cruenta. Este trabajo se inscribe dentro del propósito de revisar el proceso de Independencia no desde el prisma de la guerra como fue la constante de la historiografía tradicional, sino desde la perspectiva de las vías negociadas.

Palabras clave: rendición, capitulaciones, guerras, Independencia, Venezuela, siglo XIX.

* Academia Colombiana de Historia. Correo electrónico: rogpitc@hotmail.com. ORCID: https://orcid.org/0000-0001-9937-0228 


\title{
Puerto Cabello: the surrender of the last monarchical bastion in Venezuela during the wars of Independence
}

\begin{abstract}
Within the framework of the commemoration of the Bicentennial of the period of Independence of the Hispano-American nations, this article aims to analyze the process of surrendering the city of Puerto Cabello, the last bastion of the monarchical regime in Venezuela. After signing the capitulations, several stages can be identified that will be examined throughout this article: surrender, swearing-in, demobilization, weapons delivery and reintegration. This peaceful way was, in real terms, a reasonable option of the two sides in the final phase of a long and bloody war. This work is part of the purpose of reviewing the process of Independence not from the prism of war as was the constant of traditional historiography but from the perspective of negotiated pathways.
\end{abstract}

Key words: Surrender, capitulations, wars, Independence, Venezuela, 19th century.

\section{INTRODUCCIÓN}

7 uerto Cabello ${ }^{1}$ fue uno de los puertos estratégicos en la capitanía de Venezuela en tiempos del dominio hispánico gracias a su ubicación en la Costa Caribe y por ser el principal punto de entrada de armas y elementos de guerra desde el siglo XVIII. Sus fortificaciones fueron diseñadas para defender esta costa de los intentos de invasión marítimos de corsarios ingleses.

Las guerras de Independencia de Venezuela registradas a principios del siglo XIX se caracterizaron por ser un conflicto largo y con un fuerte componente de retaliaciones atizadas por los odios raciales. Entre todas las ciuda-

1 Ésta es la descripción que hace el historiador Baralt sobre el complejo plano geográfico de esta ciudad: "Lo que se llama pueblo interior de Puerto Cabello, se halla construido en una pequeña península que se prolonga hacia el norte de la costa y está fortificado por el sur, que mira al pueblo exterior, y por el occidente hacia la entrada del puerto: por el norte hay un canal profundo que lo separa de la isleta en donde se halla construido el castillo que defiende la entrada. Por la parte que el castillo resguarda no está fortificado, ni tampoco por el naciente en que la naturaleza lo ha defendido con un extenso manglar, de poco fondo en la baja marea y tenido por invadeable hasta entonces”. Baralt, Díaz, Resumen de la historia de Venezuela, Cabimas, UNERMB, 2016, p. 182. 
des, Puerto Cabello cumplió un papel protagónico en el desarrollo de estos acontecimientos políticos y militares aunque no todas sus fortificaciones fueron utilizadas por cuanto estaban bastante deterioradas. ${ }^{2}$

El 5 de julio de 1811 fue firmada el acta de independencia de Venezuela y al cabo de un mes Puerto Cabello consiguió el rango de ciudad. El 30 de junio del año siguiente, los españoles prisioneros que se hallaban en el castillo de San Felipe protagonizaron una sublevación y lograron apoderarse de este fortín que estaba al mando del joven coronel Simón Bolívar, apresando a la guarnición y bombardeando la ciudad. Tras la caída de esta plaza el general republicano Francisco Miranda no tuvo más remedio que capitular en San Mateo el 25 de julio culminando así la primera fase republicana en Venezuela.

Los patriotas en cabeza de Manuel Piar y del coronel Bolívar establecen el bloqueo y a finales de 1813 recuperan la plaza y se abre paso a la Segunda República. Al año siguiente, los realistas vuelven a ganar terreno y bajo la orientación de José Tomás Boves logran apoderarse de esta localidad con lo cual culmina el experimento de la Segunda República.

En 1815 llega el Ejército Expedicionario de Reconquista y hace escala en Puerto Cabello en donde se abastece de recursos y pie de fuerza para continuar su ofensiva en el resto del territorio venezolano y en la Nueva Granada. $^{3}$

Hacia 1817 Simón Bolívar liberó la provincia de Guayana desde donde organiza su apoyo a la liberación de la Nueva Granada y se instala el Congreso de Angostura que le imprime un respaldo institucional y liberal al proyecto independentista. Para agosto de 1819, Bolívar logró coronar con éxito su campaña militar que le permitió apoderarse de la ciudad de Bogotá y liberar la parte central y oriental del territorio neogranadino después de lo cual los esfuerzos se concentraron en la liberación de Venezuela. Después de este triunfo militar, el 17 de diciembre, el Congreso de Angostura aprueba la Ley Fundamental de la República que crea la República de Colombia. De este modo se consolidó oficialmente la unión de la Nueva Granada y Venezuela dentro de la lucha conjunta de ambos pueblos por lograr la Independencia.

Hacia el año de 1820 irrumpió en España la esperanza de una salida negociada a esta guerra que llevaba más de una década causando desolación y destrucción. Después del levantamiento de Riego, fueron convocadas las

2 Zapatero, Historia de las fortificaciones de Puerto Cabello, Caracas, Banco Central de Venezuela, 1977, p. 215.

3 La Nueva Granada era el territorio con el que se conocía lo que hoy corresponde en términos generales a la República de Colombia. 
Cortes y se restableció la Constitución de Cádiz a la cual el Rey Fernando VII elevó su juramento. Las Cortes manifestaron su intención de restaurar el dominio español en América a través de una amnistía general, para lo cual se mostraron dispuestas a hacer concesiones prometiendo a las fuerzas insurgentes que conservarían el poder de las provincias que hubiesen conquistado, pero con la condición de que éstas debían depender de España. ${ }^{4}$

En desarrollo de esta directriz, a mediados de este año iniciaron en Venezuela los primeros acercamientos que, tras múltiples obstáculos, conllevaron al ejército español en cabeza del general en jefe Pablo Morillo y al gobierno republicano, bajo el mando del presidente Simón Bolívar, a firmar en la población de Trujillo el 25 de noviembre un tratado de armisticio que se extendería durante seis meses para propiciar el ambiente que condujera a la firma de una paz definitiva. Al día siguiente, las partes firmaron un tratado de regularización de la guerra que concentró su atención en la protección a los prisioneros y a los heridos en campaña. ${ }^{5}$

Las continuas infracciones al acuerdo de tregua y, especialmente, el alzamiento emancipador ocurrido el 28 de enero de 1821 en Maracaibo precipitaron el rompimiento de esta tregua a principios del mes de mayo, después de lo cual los republicanos le imprimieron un mayor respaldo institucional a su proyecto político a través de la instalación del Congreso de Cúcuta y la promulgación de la Constitución de la República de Colombia al tiempo que en el plano militar lanzaban la campaña para liberar a Venezuela logrando el triunfo en la batalla de Carabobo el 24 de junio, despejándose así el camino para recuperar la ciudad de Caracas. Luego de esta victoria, el derrotado general Miguel de La Torre, quien había asumido la comandancia del ejército español en reemplazo del general Morillo, logró hábilmente replegarse y buscar refugio en Puerto Cabello que en ese momento se erigía como el único bastión monárquico. Según estimativos del bando republicano, fueron aproximadamente 2.000 militares derrotados los que se dirigieron hacia aquel puerto. ${ }^{6}$ Desde este momento comenzaron los intentos de los republicanos para dominar aquella plaza que apenas sobrevivía gracias al apoyo recibido por vía marítima de Puerto Rico y Cuba. Hacia el mes de octubre los patriotas recuperaron en su totalidad la Costa Caribe neogranadi-

4 Academia Colombiana de Historia, Fondo Archivo del General Miguel de la Torre, tomo I, pp. 112-116.

5 Gaceta de Caracas, núm. 19, Caracas, Imprenta de J. Gutiérrez, 6 de diciembre de 1820, p. 95; Correo del Orinoco, núm. 91, Angostura, Impreso por Tomás Bradshaw, diciembre 30 de 1820, pp. 1-2.

6 Gaceta de Caracas, núm. 3, Caracas, julio 4 de 1821, p. 12; Thibaud, Repúblicas en armas. Los ejércitos bolivarianos en la guerra de Independencia en Colombia y Venezuela, Bogotá, Planeta-IFEA, 2003, p. 363. 
na al capitular los españoles que guarnecían la amurallada ciudad de Cartagena, pero por otro lado, los intentos de negociación de paz en España se vieron frustrados al ser expulsados de la península los comisionados republicanos José Rafael Revenga y José Tiburcio Echeverría. ${ }^{7}$

Aun con todas sus falencias y tropiezos, no cabe duda de que el tratado de armisticio y el de regularización de la guerra suscritos el 25 y 26 de noviembre de 1820 en Trujillo sirvieron de inspiración para explorar vías de conciliación más allá de la truncada tregua. Una de sus consecuencias más evidentes fueron las firmas de las capitulaciones que, para el caso de Venezuela, permitieron la liberación de los últimos bastiones del régimen monárquico en esta última fase del período de Independencia: Cumaná, Maracaibo y Puerto Cabello. Gracias a este tipo de acuerdo se logró salvar la vida de miles de combatientes españoles.

La capitulación es un convenio político y militar mediante el cual se estipula la entrega o rendición de una plaza. Esto implica la posesión del fuerte o ciudad y el destino de la guarnición de la defensa sobreviviente. Este tipo de acuerdo se negociaba por medio de emisarios y, por lo general, lo aceptaba el defensor de la plaza tras el ultimátum lanzado por el sitiador antes de que se intensificaran los rigores y estragos de un eventual asalto final y ante la inminente amenaza de un aniquilamiento masivo. Así entonces, se estipulaban "[...] ciertas ventajas para el vencido a cambio de acortar el premio del vencedor". 8

Las capitulaciones implicaron un reordenamiento de la regularización de la violencia bajo reglas que propendían por la paz. Con estos acuerdos se evitaron premeditadamente la ocurrencia de grandes batallas, lo que ayudó a crear un ambiente de confianza y de reconocimiento del otro. ${ }^{9}$

En el marco de la conmemoración del Bicentenario del período de Independencia de las naciones hispanoamericanas, este artículo tiene por objeto analizar el proceso de rendición de la ciudad de Puerto Cabello, último bastión del régimen monárquico en Venezuela. Tras la firma de las capitulaciones convenidas para esta plaza, se pueden identificar en términos generales varias etapas claramente definidas que serán examinadas a lo largo de este artículo: la rendición, la juramentación, la desmovilización, la entrega de armas y la reinserción.

7 Earle, España y la Independencia de Colombia, 1810-1825, Bogotá, Universidad de Los Andes, 2014, p. 198.

8 Cabanellas, Diccionario militar, aeronáutico, naval y terrestre, Buenos Aires, Bibliográfica Omeba, 1963, tomo I, p. 711.

9 Alfaro, La Independencia de Venezuela relatada en clave de paz. Las regulaciones pacíficas entre patriotas y realistas (1810-1846), Castellón, Universitat Jaume, 2013, pp. 345, 590. 
Este trabajo se inscribe dentro del propósito de revisar el proceso de Independencia no desde el prisma de la guerra como fue la constante de la historiografía tradicional, sino desde la perspectiva de las vías negociadas. Para la elaboración de esta investigación se adelantó la consulta de fuentes primarias de archivo, particularmente los fondos documentales que reposan en el Archivo General de la Nación de Colombia. El intercambio epistolar entre los dirigentes políticos y militares, así como también las proclamas, los partes de batalla y los informes oficiales representaron nuevas posibilidades para hallar datos que resultaron útiles para este trabajo.

\section{ENTRE EL BLOQUEO Y LOS PRIMEROS ACERCAMIENTOS}

Pocos meses después de haber buscado refugio los restos del ejército expedicionario español en Puerto Cabello, surgió por parte de los españoles una propuesta conciliadora. El 14 de enero de 1822 el general La Torre envió una carta al general José Antonio Páez, comandante general de las tropas republicanas en Valencia, en la que le informaba haber recibido órdenes de la Corte de España para concluir un tratado de paz con el gobierno independiente al mando del general Bolívar, todo con miras a poner término a la guerra que había desolado a la "gran familia española" ubicada a uno y otro lado del Atlántico. Para ello, se solicitaron salvoconductos para los comisionados españoles Marqués de Casa de León, jefe político de esta provincia, y para el coronel José María Herrera, cuya misión sería entrevistarse con el general Bolívar, quien en ese momento se hallaba organizando la guerra en el Sur para la liberación de las provincias de Pasto y Quito. De igual modo, La Torre le comunicó que había recibido órdenes de suspender las hostilidades y se propuso lo mismo al gobierno republicano, el cual a su vez debía enviar sendos comisionados hasta la localidad de San Esteban para señalar los límites de ambas jurisdicciones y convenir lo atinente a las garantías y seguridad de los habitantes de estos territorios. El general Páez contestó expresando su júbilo por esta disposición del gobierno español y de inmediato envió los salvoconductos correspondientes para el viaje de los comisionados. $^{10}$

$\mathrm{Al}$ enterarse de estas intenciones el general Bolívar solicitó al vicepresidente Santander que los recibiera en calidad de jefe del gobierno ejecutivo, tal como lo contemplaba la recientemente promulgada Constitución de la 
República. ${ }^{11}$ Esto le permitiría a Bolívar concentrarse en la guerra del Sur y le daría mayores posibilidades de conocer primero cuál era realmente la voluntad de paz que se revivía en Venezuela como buen precedente para los ofrecimientos conciliadores que había formulado hacía poco tiempo al presidente de Quito, don Melchor de Aymerich. ${ }^{12}$ Finalmente, esta propuesta se vio frustrada, pues nunca se enviaron los delegados para iniciar el diálogo.

Entre tanto, las operaciones en territorio venezolano no habían cesado. El 20 de febrero el vicepresidente Carlos Soublette dictó un decreto en el que impuso un "riguroso" bloqueo ordenando la concentración de todas las fuerzas marítimas disponibles al frente del puerto. ${ }^{13}$ En tierra las huestes patriotas bajo la orientación del general Páez incrementaron también su asedio (véase Mapa 1) con un pie de fuerza de 3.279 hombres que con el paso de los días terminó menguado por causa de las enfermedades y de las deserciones. ${ }^{14} \mathrm{El} 1^{\circ}$ de marzo este general rodeó la ciudad después de haber ocupado Borburata en momentos en que desde España se daban órdenes al gobierno de Cuba para auxiliar Puerto Cabello. ${ }^{15}$

Un nuevo antecedente se registró el 24 de abril de 1822 cuando el general Páez logró rendir por medio de capitulación el mirador de Solano, ${ }^{16}$ un sitio estratégico que permitía divisar desde lo alto a Puerto Cabello. A finales de mayo, la situación para el ejército sitiador no era muy alentadora. Una "peste de calenturas" había producido 200 enfermos y una gran cantidad de muertos. La propagación de esta fiebre se tornaba más preocupante ante la falta de medicinas y atenciones en el hospital militar mientras se veía cómo entraban fragatas para proveer de víveres a la plaza. El general Páez lanzó un vehemente llamado para buscar alternativas tendientes a frenar la introducción de alimentos a aquella plaza y solicitó a la escuadra republicana cooperar insistentemente en ese sentido. Por estos días había llegado el intendente de Orinoco con siete buques de guerra para reforzar el bloqueo marítimo sobre Puerto Cabello. ${ }^{17}$

Constitución de la República de Colombia, impresa en la Villa del Rosario, Filadelfia, Juan F. Hurtel, Impresor, 1822.

12 O'Leary, Memorias del General O'Leary, tomo XIX, p. 190.

13 Documentos relativos al bloqueo de Puerto Cabello por los patriotas después de la batalla triunfal de Carabobo, Boletín de la Academia Nacional de la Historia, año I, tomo I, núm. 2, Caracas, Academia Nacional de la Historia, junio 30 de 1912, pp. 123-125. Páez, Autobiografía, tomo I, Medellín, Editorial Bedout, 1973, p. 221.

15 Franco, Documentos para la historia de Venezuela existentes en el Archivo Nacional de Cuba, La Habana, Archivo Nacional de Cuba, 1960, p. 165.

16 Baralt, Díaz, Resumen de la Historia de Venezuela, p. 182.

17 O’Leary, Memorias del General O'Leary, tomo XIX, pp. 265, 267. 


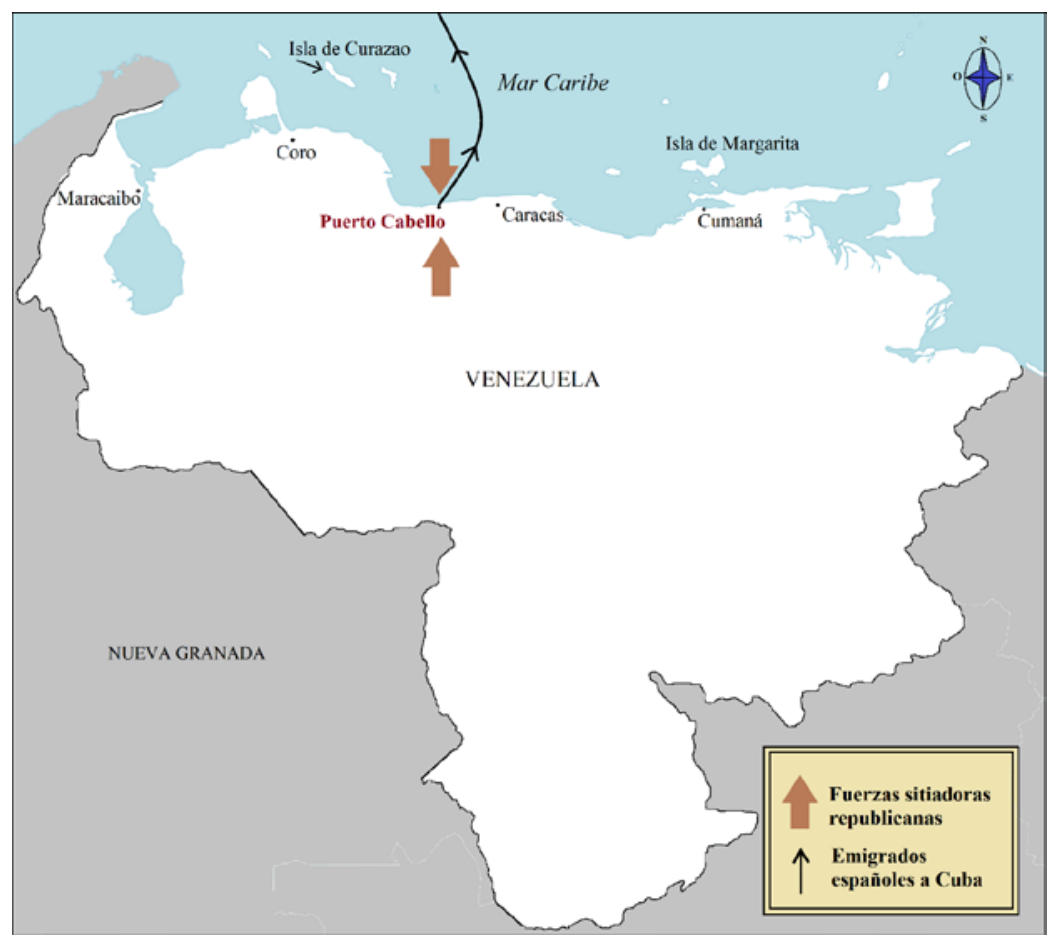

Mapa 1. Ubicación geográfica del sitio de Puerto Cabello, establecido entre 1822 y 1823 con la señalización de la ruta de los emigrados.

La Torre recibió órdenes superiores para cambiar de destino y entonces fue nombrado gobernador de la isla de Puerto Rico. En su reemplazo, el 3 de agosto asumió funciones el general Francisco Tomás Morales, quien desde un comienzo mostró una actitud más ofensiva que la de su predecesor, pues su campaña de Occidente culminó exitosamente el 7 de septiembre con la recuperación de la plaza de Maracaibo. ${ }^{18}$ Días después las huestes republicanas bloquearon la ciudad con una escuadra de nueve buques, pero fueron derrotadas por la flota española al mando de Ángel Laborde, acción victoriosa que hizo merecedor a este oficial de la cruz de la Orden del Rey Carlos III. A finales de agosto arribó a Puerto Cabello el general español Sebastián de la Calzada, procedente de la isla de Curazao, y quien era un experimenta- 
do militar que cumplía ya varios años en defensa de las banderas del Rey, cuya presencia avivó el ánimo entre la guarnición para salvaguardar hasta el final esta plaza, mientras otros soldados decidían más bien huir a las colonias extranjeras. ${ }^{19}$

Entre tanto, la presión sobre Puerto Cabello no cesaba. Una de las consecuencias de esta presión sucedió el 28 de octubre de 1822 cuando el capitán Raimundo Cobo Montero, comandante español del fuerte de La Vigía de Puerto Cabello defendido por 25 hombres, se sintió asediado y sin posibilidades de reacción ofensiva ante lo cual propuso al general Páez una capitulación. La pérdida de este punto fue lamentable para los españoles por cuanto desde allí se transmitían mensajes. Después de esta toma los sitiadores dominaron todas las posiciones y pudieron adelantar sus trincheras causando más daño a los que defendían la plaza. ${ }^{20}$

En la rendición de este fuerte se acordó que los oficiales, sargentos y soldados conservarían sus armas, vestuario, dinero, equipos y los muebles y utensilios, así como también los papeles y órdenes que les fueran útiles. La guarnición sería conducida por cuenta de la República hasta la isla de Puerto Rico, manifestando el jefe del sitio la ruta que se habría de seguir, así como día de embarque.

Los sitiadores se quedarían con los enfermos y heridos en el caso que ellos no quisieran o no pudieran seguir, para lo cual debían ser atendidos cuidadosamente y, una vez restablecidos, debían ser remitidos del mismo modo que la guarnición. Los sargentos y soldados debían entregar sus armas en el sitio en donde permanecían y sólo podían recuperarlas cuando llegaran a aquella isla del Caribe. Todo el destacamento debía ser socorrido con recursos del gobierno republicano mientras permaneciera en sus dominios y bajo sus órdenes, con igual ración que la del ejército sitiador. El general Páez aceptó estas condiciones y ordenó esa misma tarde la entrega del fuerte con todo el armamento y municiones al comandante de artillería, el capitán Santiago Mancebo. ${ }^{21}$ A pesar de esta victoria parcial de las fuerzas sitiadoras, faltaría aún mucho trecho para doblegar la guarnición que defendía la plaza de Puerto Cabello.

González, La guerra de Independencia en Puerto Cabello, Caracas, Ediciones del Congreso de la República, 1988, p. 311.

20 Restrepo, Historia de la Revolución, tomo III, p. 343.

21 Colección de documentos relativos a la vida pública del Libertador, Caracas: Imprenta de Devismes Hermanos, 1826, tomo tercero, pp. 178-179; Pérez, "Relación de prisioneros realistas. Datos y hechos para el estudio de la Guerra de Independencia y el Derecho Internacional de Guerra y Humanitario", "Boletín de la Academia Nacional de la Historia", tomo LXXXII, núm. 325, Caracas, Academia Nacional de la Historia, enero-marzo de 1999, pp. 138-139. 
En España, entre tanto, no cesaba el ambiente de convulsión política entre la tendencia liberal y los que aspiraban a restablecer el absolutismo. Los españoles sufrieron un duro revés el 24 de julio de 1823 en la batalla naval de Maracaibo, y después de esto se vieron conminados a rendirse y a firmar capitulaciones. Así quedaba únicamente Puerto Cabello como el último bastión español en territorio venezolano.

Con la destrucción de buena parte de la flota española en Maracaibo y la salida de una parte de ella para Cuba, los realistas vieron desvanecidas las esperanzas de reforzar a Puerto Cabello. Las posibilidades de recibir refuerzos desde España eran cada vez más remotas. ${ }^{22} \mathrm{El}$ camino le había quedado más despejado a Páez, quien concentró aún más sus esfuerzos en acentuar el bloqueo sobre esta plaza al movilizar las fuerzas terrestres y marítimas disponibles. Una de sus primeras acciones en tal sentido consistió en marchar hasta el puerto de La Guaira para activar la conducción del mortero, la artillería y demás elementos de guerra en los bergantines Urica y Pichincha, naves que sirvieron para impedir la entrada de víveres a la sitiada plaza. ${ }^{23}$

Cuando Páez adelantaba esta operación se enteró de la desesperación y del conflicto interno que se palpaba entre los vecinos y la guarnición española de la plaza, pues muchos estaban ansiosos de que se pactara una capitulación que evitara las desgracias que se presagiaban por el estado de indefensión en que se hallaban. Habiendo confirmado esta noticia con cartas particulares provenientes de Curazao, el general republicano tomó la decisión de abrir negociaciones con la esperanza de que tendrían feliz término. Marchó entonces con celeridad, pero sin dejar de agilizar la remisión de buques y demás elementos de guerra que estaban preparando para el sitio de la plaza. ${ }^{24}$

Al momento de comparar las opiniones sobre cuál debía ser la estrategia del gobierno republicano con relación a Puerto Cabello, vale aclarar que no toda la oficialidad se inclinaba por aplicar una vía negociada en este último puerto bajo dominio español. El vicepresidente de Venezuela, don Carlos Soublette, era uno de ellos. Pocos días después de rendida Maracaibo, él pensaba que el alto gobierno debía enviar una gran cantidad de recursos, al menos 600.000 pesos, para supervivencia de la tropa en esta región costera y para auxiliar la operación de la toma de Puerto Cabello. En esta área eran escasos los recursos con los que se contaban y se hacía imperioso estimular a la Historia, p. 358.

23 Restrepo, Historia de la Revolución de la República de Colombia, Bogotá, Editorial Besanzon, 1858, tomo III, p. 341.

24 Archivo General de la Nación (AGN), Sección República, Fondo Secretaría de Guerra y Marina, tomo 39, f. 323r. 
la marina —en su mayoría extranjera - al servicio de las banderas republicanas. Soublette era consciente de la inferioridad de la marina americana, con lo cual quiso sugerir que la toma debía lanzarse por tierra. En vista del estado deficitario de las arcas oficiales de Caracas, Soublette hizo este llamado de ayuda a su homólogo, el vicepresidente neogranadino Francisco de Paula Santander. Sus expectativas apuntaban a que este último bastión de la monarquía debía ser recuperado antes de finalizar el año. ${ }^{25}$

Mucho más moderada y reflexiva fue la posición asumida por el vicepresidente Santander, quien a fin de cuentas era el directamente encargado de la financiación de la guerra en todo el territorio de la República de Colombia. A finales de agosto, este alto funcionario le recomendó al general Páez que exigiera la rendición de Puerto Cabello apoyándose en el capítulo primero de las capitulaciones pactadas en Maracaibo y que evaluara con la alta comandancia militar de Venezuela las posibilidades reales de conseguir el éxito por la vía militar. Incluso, Santander había pensado tramitar con los agentes diplomáticos en Estados Unidos la compra de una fragata y 12 cañones con recursos del empréstito que se estaba gestionando en Europa, además de lo cual se habían adelantado gestiones con el gobierno de Chile para el suministro de embarcaciones. ${ }^{26}$ Todo esto porque era consciente del estado deficiente de las fuerzas republicanas que establecían el sitio en esos momentos, circunstancias bajo las cuales era imposible doblegar la defensa de la guarnición española. ${ }^{27}$

No obstante, semanas después, el general Santander insistió en que lo mejor era la toma violenta de este puerto y así se lo hizo saber en una carta transmitida al general Páez para que llevara a cabo esta operación a costa de cualquier sacrificio; para ello ofreció remitirle 30.000 pesos. El problema fue que esta carta llegó muy tarde, cuando ya se habían firmado las capitulaciones.

El contexto político externo para la causa emancipadora no era muy alentador por cuanto en este año de 1823 se temía que la Santa Alianza, que había restablecido la monarquía absoluta en España, la apoyara para que recuperara sus dominios americanos. Un resultado de este temor fue el decreto dictado el 4 de julio en el que se decidió expulsar a los americanos y

Cortázar, Correspondencia dirigida al General Santander, Bogotá, Academia Colombiana de Historia, 1969, vol. XII, pp. 229-231.

26 Restrepo, Documentos importantes para la historia de la Revolución de la República de Colombia en la América Meridional, Medellín, Universidad de Antioquia-Universidad Nacional, 2009, CD, p. 864.

27 O'Leary, Memorias del General O'Leary, tomo III, p. 117. 
españoles que se consideraban peligrosos por su simpatía con la bandera independentista. ${ }^{28}$

\section{INTENTOS DE NEGOCIACIÓN}

El proceso de negociación en torno a la rendición de Puerto Cabello se extendió durante 72 días. Fue, a decir verdad, un proceso largo y complicado, pues antes de que se cristalizara el acuerdo final fueron necesarios más de tres intentos de diálogo por parte de Páez y se cruzaron más de 15 cartas llenas de vacilaciones, recriminaciones mutuas y posiciones radicales. ${ }^{29}$ No es difícil entender la obstinación de aquellos militares españoles que tras varios años de lucha no querían ver vulnerado su orgullo al entregar este último bastión de la monarquía.

El 28 de agosto de 1823, desde el cuartel general de Valencia, el general Páez envió una comunicación al comandante Manuel Carrera de Colina, comandante en jefe de la plaza de Puerto Cabello. Aprovechó la ocasión para adjuntarle el texto de la capitulación recientemente pactada en Maracaibo, después de lo cual advirtió haber concentrado todas sus tropas en recuperar aquella plaza. En su comunicación Páez aseguró que contaba con un pie de fuerza suficiente para atacar, pero también era consciente de los sacrificios y víctimas que esto acarrearía. Por ello, planteó este alto oficial la posibilidad de entrar en diálogos que desembocaran en un arreglo que les permitiera a los republicanos recuperar todo el territorio venezolano y a salvaguardar la vida de la población y de la guarnición. Según recordó Páez, ninguna esperanza podían abrigar los españoles allí presentes de volver a la península, pues era conocido el estado de convulsión política allí imperante.

Páez hizo énfasis en su capacidad de fuerza conformada por buques de guerra, fuerzas sutiles y un ejército poderoso en tierra, además de la creciente opinión favorable hacia la bandera republicana, recursos que consideraba más que suficientes para ganar por la vía de las armas lo que eventualmente se podía acordar por medio de la conciliación. Estaba además convencido de que esta vía pacífica sería aprobada y valorada por las naciones “cultas” de todo el mundo. Éstas fueron las palabras con las que intentó persuadir al oficial español: “[...] más gloria pueda vuestra señoría conseguir por una deferencia justa y prudente que por una obstinación desesperada y estéril drid, Editorial Tecnos, 1979, p. 33.

29 Archivo del General José Antonio Páez, 1818-1820, Bogotá, Editorial “El Gráfico”, 1939, tomo segundo, pp. 208-310. 
irreconciliable con los intereses, propiedad, seguridad y existencia de estos vecinos y guarnición”. ${ }^{30}$

Páez expresó su fiel promesa de elaborar las bases de un arreglo justo que salvaguardara el honor de aquel jefe español y estaba dispuesto a adoptar decisiones en favor del afligido pueblo de aquella plaza siempre que fueran compatibles con las leyes de la República.

Esta invitación fue conducida por un edecán del general Páez, quien luego de acercarse a la plaza y anunciar su misión, fue abordado por militares españoles que lo notificaron con la respuesta escueta de haberse recibido perentorias órdenes superiores de no recibir ninguna comunicación del gobierno republicano. Al verse desconcertado con esta actitud de rechazo, Páez vio agotados los canales de "la moderación y la política" y consideraba indispensable recurrir al uso de la fuerza. De cara a este panorama, a principios de septiembre en carta remitida al secretario de Guerra, Pedro Briceño Méndez, estimó que era el momento preciso de preparar los buques mayores con todo el armamento disponible, con cuya acción creía que la plaza podía tomarse en unos pocos días. ${ }^{31}$

Páez estaba convencido de que la rendición de Maracaibo había sido "un golpe fatal para el enemigo” y por ello creía firmemente en la necesidad de concentrar todos los recursos militares para propinarle a aquellos reductos españoles de Puerto Cabello "un golpe de mano". ${ }^{32}$ La debilidad en que se hallaba este puerto le hacía presagiar con optimismo que podría alcanzar el éxito militar de manera fácil y rápida.

Sin embargo, el general Páez no dejó de explorar otro tipo de fórmulas persuasivas. Una de ellas consistió en enviar un oficio a don Jacinto Iztueta, uno de los hombres más influyentes de la plaza, quien había pasado de ser furibundo seguidor de la bandera monárquica a ser un defensor de la causa independiente. Él era visto como una ficha clave para fraguar un movimiento interno que obligara a Calzada a rendirse.

El 17 de septiembre, estando Páez en La Guaira acopiando algunos elementos de guerra para el sitio, despachó secretamente una carta al jefe de esta plaza el brigadier Sebastián de la Calzada, convidándolo a deponer las armas para evitar una gran efusión de sangre y ofreciéndole 25.000 pesos para los gastos, lo cual implicaba la salida de su plaza.

Para llevar esta carta, empleó dos presidiarios, quienes fueron embarcados con grillos desde Ocumare. Aquel alto oficial les encomendó que se presentaran ante Calzada como prófugos de las prisiones de La Guaira. La

Archivo del General José Antonio Páez, tomo segundo, p. 208.

AGN, Sección República, Fondo Secretaría de Guerra y Marina, tomo 39, f. 311r, 314r.

Cortázar, Correspondencia dirigida, vol. X, p. 134. 
respuesta de este experimentado oficial español, también secreta, fue inmediata y contundente. Manifestó que su responsabilidad y su honor le impedían dar el paso de conciliación propuesto y reafirmó su intención de salvaguardar la plaza a su mando hasta el último aliento. ${ }^{33}$

Tras fijar su cuartel general en la alcabala del Paso Real, al frente de la plaza, con una columna de 300 infantes y 25 lanceros, el 23 de septiembre el general Páez formalizó un tercer intento de acercamiento. En una comunicación dirigida al general Calzada, Páez renovó prácticamente los mismos términos de su carta oficiada días antes al coronel Carrera. Aquel oficial patriota informó que estuvo a punto de iniciar el ataque, pero detuvo sus planes en consideración a la lamentable situación de las víctimas que debían presentar su rendición. A Calzada le advirtió que, concentradas todas las fuerzas contra esa plaza, no tenía ninguna escapatoria hacia otro puerto, además de las nulas posibilidades de socorro desde la península ibérica que en ese momento estaba abrumada por agitaciones internas, cuyo resultado dejaría sin muchas opciones de recuperar estas tierras del Nuevo Mundo. Ninguna esperanza le vaticinaba Páez a las tropas españolas de defender la plaza y mucho menos de intentar operaciones sobre el territorio interior dominado íntegramente por los republicanos. Cualquier operación que planeara Calzada y sus huestes sería, según Páez, una "obstinación estéril y desesperada" que sólo traería incontables víctimas, huérfanos y derramamiento de sangre. Aquel general venezolano prometió que con la vía de la conciliación podían renacer los vínculos de amistad y contarían tanto los ciudadanos como los militares realistas con las garantías que ofrecían las leyes republicanas. Como parte de sus intentos conciliadores, Páez había escrito una carta al cabildo de la ciudad para que, como representante y protector del pueblo, supieran el peligro inminente en que se hallaban avocados y propendieran por la ruta del diálogo.

Ese mismo día contestó Calzada aduciendo que resultaban en vano los argumentos esgrimidos por Páez y que la ostentación del poderío de sus fuerzas eran una exageración. Este comandante español se redujo a reafirmar que únicamente cumplía con su deber en el marco de la guerra. Calzada devolvió la carta adjunta que Páez había dirigido al cabildo, haciéndole saber que sólo tenía que entenderse directamente con la autoridad militar y con ninguna otra. ${ }^{34}$

Al día siguiente, Páez contestó aclarando que no estaba dimensionando la magnitud de las fuerzas y recursos con que contaba para sobreponerse en la plaza, capacidad que había sido puesta a prueba en la conquista de otros

AGN, Sección República, Fondo Secretaría de Guerra y Marina, tomo 39, f. 324r. 
bastiones monárquicos. Contundente y perentoria fue la advertencia a su contraparte para que de una vez por todas reflexionara y atendiera esta proposición de paz o, de lo contrario, arremetería sin piedad y sin oír ningún llamado de humanidad.

El cruce epistolar no cesó y el general Calzada subrayó el hecho de que así fuera un reducido grupo de "soldados viejos que sabían cumplir su deber”, resistirían hasta el postrer momento y, por ello, le reiteró a Páez no menospreciar las capacidades del ejército español. Le advirtió a su oponente que si tenía la suerte y la osadía de franquear los muros del castillo, su nombre y su gloria serían manchadas por su accionar como "sanguinario" que solo dejaría una estela de destrucción. ${ }^{35}$

Al advertir Páez la reiterada negativa del jefe de la plaza y su incredulidad frente al volumen de las tropas efectivas republicanas, optó por suspender la última y decisiva invitación de paz hasta reunir íntegramente la fuerza destinada para el asedio, con la esperanza de que así la República podía quedar en posesión de aquel bastión realista sin causar tanto "estrago y desolación”.

No obstante, Páez siguió aferrado a la esperanza de concretar una solución concertada. El 3 de octubre, desde su cuartel general de Paso Real, siguió persuadiendo a Calzada sobre lo inútil que resultaba la vía armada estando de por medio la vida de miles de militares y pobladores. De nada creía Páez que valía en este caso el valor extremo por la gloria de España. Se reconocía que la plaza era fuerte en su construcción material, pero vulnerable por estar en este momento aislada, desguarnecida y sin los recursos indispensables para defenderse de un ataque. Instó a su contraparte a nombrar de inmediato comisionados que redactaran los tratados para no tener que presenciar el llanto, las ruinas y una gran cantidad de cadáveres. En su carta de contestación, Calzada siguió obstinado en su derecho natural de defensa, para lo cual no dudó en reafirmar que harían todo lo posible para aminorar los estragos de la confrontación. ${ }^{36}$ Este comandante español hacía angustiosos llamados al gobierno español de Cuba para el envío de auxilios, pero la respuesta fue muy corta debido al estado deficitario de esta isla caribeña. ${ }^{37}$

Por estos días logró ingresar un barco procedente de Curazao y varios de los viajeros difundieron la noticia sobre la expedición de una ley dictada por el vicepresidente Soublette, la cual ordenaba la expulsión de todos los españoles ${ }^{38}$ desafectos al sistema americano. Esta información desanimó a los

\footnotetext{
Páez, Autobiografía, tomo I, p. 233.

AGN, Sección República, Fondo Secretaría de Guerra y Marina, tomo 39, f. 344r-345r.

Franco, Documentos para la historia, p. 220.

AGN, Sección República, Fondo Secretaría de Guerra y Marina, tomo 41, f. 173r.
} 
aliados republicanos que había en la plaza y que estaban trabajando sigilosamente para obligar al comandante español a entrar en convenio. Ya desde finales de agosto, el secretario de Guerra había recomendado a Páez conceder gratificaciones a estos aliados al interior de la plaza, tanto en el vecindario como en la guarnición, pero sin descuidar las labores de alistamiento militar. El principal contacto era un español con quien se mantenían fluidas comunicaciones secretas. Algunos oficiales y soldados ya habían manifestado su aspiración a quedarse en estos territorios donde tenían sus mujeres, sus hijos y sus medios económicos de subsistencia.

No se imaginó Páez que tal noticia iba a causar tanto escándalo y estrépito al interior de la plaza, lo cual terminó por malograr sus planes con los infiltrados comprometidos que empezaron a desconfiar de la seguridad y cumplimiento de las ofertas. Ante esta circunstancia adversa, el comandante republicano retiró sus ofertas y prometió intervenir como mediador ante el intendente del Departamento de Venezuela para implorar que se suspendiera la ejecución de dicha ley, mientras se solicitaba al alto gobierno limitar los alcances únicamente a los desafectos que fueran motivo de peligro para la seguridad pública.

En su exposición de motivos, Páez reiteró los traumatismos que aquellas normas podían causar en los avances logrados en su propósito central de lograr la rendición del único puerto que hacía falta para poseer íntegro el territorio venezolano. Pedía, en ese sentido, tener consideración con buena parte del pueblo que vería arrancar del seno de sus familias a muchos vecinos pacíficos sin más delito que el haber nacido en la península ibérica. Hacía ver también Páez que con la inminente toma de la plaza cesaría la desconfianza y se acabarían los temores, pues los españoles perderían la esperanza de una contraofensiva y, de esta forma, se acostumbrarían a vivir en tranquilidad entre los criollos y naturales de estos territorios, contribuyendo con sus trabajos al aumento de la riqueza y prosperidad de sus familias y de estas provincias americanas.

Al conocer estas inquietudes, fueron debatidas en Bogotá al interior del Consejo de Gobierno considerándose que la ley ya estaba en vigencia y por tanto no era conveniente revocarla porque daría muestras de debilidad del naciente gobierno republicano. Se explicó que la ley no se hacía extensiva a todos los españoles sino que exceptuaba a aquellos que hicieran servicios invaluables a la República o que fuera reconocida su decisión por la causa emancipadora. ${ }^{39}$ Tanto el secretario de Guerra como el vicepresidente neogranadino Francisco de Paula Santander hicieron énfasis en que los españo- 
les eran la causa de todos los males sucedidos durante las pasadas sublevaciones vividas en las localidades de Pasto, Ciénaga, Ocaña, Zulia y las sabanas al oeste de Cartagena. En nada pensaban estos dos altos funcionarios que la ley podía perjudicar las negociaciones de rendición de la plaza de Puerto Cabello pues si los españoles cooperaban a su entrega recibirían mejor trato que aquellos pérfidos que era necesario expulsar, tal como había ocurrido con los españoles que habían cooperado activamente en la transformación política de Panamá y en la rendición del castillo de Bocachica. Se invitó en consecuencia al general Páez para que expusiera estas concesiones en el proceso de negociación con los españoles comandantes de la plaza, pero sin llegar al extremo de derogar la ley. ${ }^{40}$

Ante la poca receptividad del comandante de la plaza a los llamados de paz, el 11 de octubre el general Páez reportó haber dirigido algunas bombas aunque no todas dieron con certeza en el blanco previsto. Un cañón bien situado a orillas del mangle y otro de 24 libras a menos de medio tiro de distancia lanzaron también disparos intimidatorios. No obstante, en una posición menos optimista y quizás más realista de la que pintaba a su adversario, Páez hacía ver a su superior, el secretario de Guerra, don Pedro Briceño Méndez, que estas hostilidades no bastarían para conseguir la rendición de esta plaza que aún presentaba varios obstáculos para ser asaltada. Este general guardaba la esperanza de que la rendición viniera por cuenta del hambre, pues las informaciones recibidas revelaban que apenas contaban con víveres para 40 días de resistencia ante lo cual estaba vigilante con las escuadras republicanas para impedir la llegada de auxilios externos. En un acto de sinceridad, Páez reconoció que requería todavía de mayores recursos y elementos de guerra para tener éxito en un eventual asalto. Para no retardar tanto la rendición, consideraba clave la llegada de al menos dos flecheras protegidas por dos bergantines para estrechar aún más el bloqueo marítimo. Guardaba también alguna ilusión de que sus aliados al interior de la plaza serían reanimados con atractivas ofertas y garantías que los impulsara a fraguar un audaz movimiento de insurrección interior que facilitara la toma de la plaza. ${ }^{41}$ En carta remitida al secretario de Guerra el 14 de octubre, Páez informó sobre los avances de esta conspiración planeada con sus vecinos aliados y algunos miembros de la guarnición española. ${ }^{42}$

40 AGN, Sección República, Fondo Secretaría de Guerra y Marina, tomo 39, ff. 343r, 346r347r.

41 AGN, Sección República, Fondo Secretaría de Guerra y Marina, tomo 39, f. 242r; Gaceta de Colombia, núm. 109, noviembre 16 de 1823, Bogotá, Imprenta de Espinosa, p. 1.

42 González, La guerra de Independencia, pp. 324-325. 
Finalmente, al ver que habían resultado inútiles sus esfuerzos por evitar las consecuencias funestas de la vía armada, a las ocho de la mañana del 31 de octubre el general Páez envió la cuarta y última intimación para la rendición de la plaza en un término de 24 horas y, en caso de no ser respondida, prometió en un tono amenazante pasar "[...] a cuchillo toda la guarnición para vengar en ella las víctimas que se han inmolado imprudentemente de los vecinos pacíficos, que son los que han sufrido en sus personas y sus casas". ${ }^{43}$

El reforzamiento del bloqueo en esos momentos consistía en un pie de fuerza terrestre de 1.200 hombres y 18 barcos al mando del almirante José Prudencio Padilla y el contraalmirante Renato Beluche. La guarnición española prácticamente se había quedado en esos momentos aislada y asfixiada por carencia de auxilios por cuanto, según la misma oficialidad reconoció, sólo les quedaban reservas de pólvora para 8 días, y víveres para 16 y con una muy exigua ración. ${ }^{44}$

La respuesta del brigadier español fue inmediata y tajante. Se negó a aceptar la proposición aduciendo que el culpable de los males de la guerra no eran quienes defendían la plaza, sino los republicanos y su incesante ánimo agresivo y provocador. Calzada insistió en salvaguardar la plaza hasta el último aliento y lanzó un llamado a Páez para que meditara muy bien la decisión que podía ser vista por otras naciones como una flagrante violación al derecho de gentes por la gran mortandad que podía producir. ${ }^{45}$

Con esta respuesta el general Páez estaba convencido de que era el momento preciso de actuar por la vía de las armas porque cualquier dilación podía darle algún respiro a la plaza y prolongar su resistencia, y así lo comunicó a sus superiores. Noticias recibidas de Curazao incrementaron las preocupaciones en el cuartel general republicano. Una de ellas hacía referencia a la debilidad del partido liberal en España y en la otra se aseguraba que estaba pronto a venir el reemplazo del general Morales y que el contraalmirante Ángel Laborde y Navarro, comandante del apostadero de La Habana, alistaba una nueva expedición con fuerzas que al sumarlas se estimaban suficientes para levantar el bloqueo de la plaza. En realidad, Páez no estaba todavía convencido de su capacidad de fuerza, pues sólo contaba con los batallones Granaderos y Anzoátegui, ante lo cual pidió el envío de uno o dos de los escuadrones que estaban en la recién liberada ciudad de Maracaibo en mejores condiciones y, adicionalmente, el refuerzo de 500 o 600 hombres de otro departamento, pues tal como estaban las cosas, resultaba prácticamente im-

AGN, Sección República, Fondo Secretaría de Guerra y Marina, tomo 39, f. 392v. 
posible reclutar tal cantidad de hombres en Venezuela en donde la experiencia había demostrado la alta propensión a desertar cerca de sus casas.

Páez debió ir a La Guaira para conseguir algunos elementos de guerra y para traer la corbeta Boyacá y el bergantín Pichincha, así como cuatro flecheras de Cumaná con el fin de que acompañaran al bergantín Urica, el único que ejercía el bloqueo sobre la plaza. Ya en operaciones, las cuatro flecheras habían servido más para intimidar que para bloquear la entrada de buques, dado lo extenso de la línea por cubrir. Las fragatas Venezuela y Bolívar no estaban habilitadas por falta de tripulación.

La línea republicana estaba situada sobre la plaza de la Constitución desde los Cocos hasta el Rebote con cinco piezas de fuerte calibre, un mortero y un obús. Aprovechando la oscuridad de la noche se construyeron los parapetos, exponiéndose los soldados a las constantes agresiones del enemigo. Las baterías estaban a tan sólo dos cuadras de las baterías españolas. Los ataques se habían concentrado en la línea exterior de la plaza contra una casa fuerte de los españoles que era el depósito de agua, observándose cómo varios vecinos sacrificaron sus vidas por ir en afanosa búsqueda del preciado líquido en medio del fuego cruzado. El nivel de confrontación era intenso logrando arruinar buena parte de las baterías de defensa. Casi todas las casas de la plaza se hallaban destruidas y sólo se alimentaban de pan, pues ya se les había agotado el tocino que tenían de reserva. Páez continuaba temeroso de la supuesta expedición de Laborde que, aunque remota, si era de la magnitud que se rumoraba, podía fácilmente derrotar la escuadra republicana.

Los ánimos de las huestes patriotas se incrementaron con la llegada del general Francisco Bermúdez y sus tropas. El golpe final a la plaza que se había pensado por el lado de la laguna no había sido posible por falta de botes, así que la otra opción era ir a pie a través de la orilla y en un medio fangoso, pero no se contaba con hombres prácticos que se atrevieran a desarrollar esta operación. ${ }^{46}$

\section{ASALTO FINAL YTÉRMINOS DE LA CAPITULACIÓN}

Finalmente, el general sitiador se decidió por lanzar el ataque militar por la parte más desguarnecida de la plaza ${ }^{47}$ En la noche del 5 de noviembre inició el planeamiento de esta operación militar para lo cual destinó al capitán de caballería Marcelo Gómez y a los tenientes del batallón Anzoátegui, José Hernández y Juan Albornoz, para que guiados por Juan Iztueta, hijo del

46 AGN, Sección República, Fondo Secretaría de Guerra y Marina, tomo 39, ff. 366r-369v.

47 Baralt, Díaz, Resumen de la Historia de Venezuela, p. 183. 
infiltrado español Jacinto Iztueta, reconocieran anticipadamente el estado de la laguna que flanqueaba la plaza por el costado derecho. En esa exploración se advirtió que, aun con cierta dificultad, podía avanzarse por ese lado en medio del lodazal de mangle. De manera sigilosa, el día 7 a las diez de la noche se dispuso que 400 hombres del batallón Anzoátegui unidos a 100 lanceros del regimiento de Honor al mando del mayor Manuel Cala atravesaran la laguna en un tortuoso recorrido de ocho cuadras e iniciaran el asalto sin ser detectados por las baterías españolas Princesa y Constitución y burlando la vigilancia de la corbeta Bailén y las lanchas de defensa apostadas en la laguna. A las dos y media de la mañana del 8 de noviembre pisó tierra la primera columna entre las dos baterías españolas que, al ser sorprendidas, iniciaron la reacción y así se rompió el fuego al interior de la plaza.

Noventa militares españoles encerrados en la casa fuerte, al verse en medio de dos líneas enemigas, solicitaron entrar en diálogos, pero los mandos oficiales republicanos los obligaron a rendirse, después de lo cual fueron interrumpidas las hostilidades. ${ }^{48}$

$\mathrm{Al}$ amanecer de ese mismo día 8 desde el castillo de San Felipe los españoles reanudaron sus acciones hasta que Páez envió un comisionado de paz. El balance de la operación militar arrojó 36 heridos y 6 muertos mientras que del lado español se contabilizaron 156 bajas y 60 heridos, además de 256 prisioneros. El botín militar de esa operación fue el decomiso de 60 piezas de artillería de todos los calibres, 620 fusiles y todo cuanto había en los almacenes. De esta forma se daba fin a 13 años de intensa lucha militar en territorio venezolano. ${ }^{49}$

El 8 de noviembre, habiéndose apoderado de la plaza, Páez envió una comunicación al coronel Manuel Carrera y Colina, quien había buscado refugio en el castillo de donde no tenía opción de salvarse. Movido por su espíritu filantrópico, propuso aquel general victorioso una capitulación "honrosa”.

Fue necesaria ese mismo día otra nota reiterativa de Páez hasta que finalmente Carrera y Colina decidió acogerse a tal ofrecimiento. Reconoció haberse demorado varias horas en su respuesta debido a que tenía que reflexionar "con mucho pulso y tino" los términos de la entrega, pues estaba de por medio la suerte de muchas personas. Por lo pronto, decretó la suspensión de hostilidades por tierra y solicitó que se extendiera también al espacio marítimo por el grado de vulnerabilidad en que se hallaba. ${ }^{50}$

AGN, Sección República, Fondo Secretaría de Guerra y Marina, tomo 39, f. 393v. 
Calzada resistió con sus hombres del Estado Mayor en el baluarte El Príncipe hasta que se vio doblegado militarmente y fue hecho prisionero. ${ }^{51}$ Por otro lado, surgió un incidente que Páez describió pormenorizadamente en sus memorias, todo suscitado a raíz de las fallas en la coordinación de las huestes españolas de la plaza para cesar hostilidades pues aún faltaba la rendición del castillo:

Estando yo en la parte de la plaza que mira al castillo, y mientras un trompeta tocaba parlamento, disparó aquel cuatro cañonazos con metralla, matándome un sargento; pero luego que distinguieron el toque que anunciaba parlamento, izaron bandera blanca y suspendieron el fuego. A poco oí una espantosa detonación, y volviendo a la vista a donde se alzaba la espesa humareda, comprendí que habían volado la corbeta de guerra Bailen, surta en la bahía. Manifesté mi indignación a Calzada por aquel acto, y este atribuyéndolo a la temeridad del comandante del castillo, coronel don Manuel Carrera y Colina, se ofreció a escribirle para que cesara las hostilidades, puesto que la guarnición de la plaza y su jefe estaban a merced del vencedor. Contestó aquel comandante que estando prisionero el general Calzada, dejaba de reconocer su autoridad como jefe superior. Entonces, devolviendo yo su espada a Calzada, le envié al castillo, desde donde me escribió poco después diciéndome que Carrera había reconocido su autoridad al verle libre, y que en su nombre me invitaba a almorzar con él en el castillo. Fiado como siempre en la hidalguía castellana, me dirigí a aquella fortaleza donde fui recibido con honores militares y con toda la gallarda cortesía que debía esperar de tan valientes adversarios. $^{52}$

Mientras estaban sentados dialogando, los soldados que habían capitulado previamente en el Mirador de Solano se presentaron ante Páez manifestándole con preocupación que aún se les seguía causa por este suceso. Pese a los argumentos de disciplina militar esgrimidos en rigor por los oficiales españoles, el general republicano intercedió en este caso para eximir a los implicados del castigo que se les había anunciado. ${ }^{53}$

El 9 de noviembre Carrera y Colina anunció que a las once de la mañana enviaría una comisión para dar principio a las transacciones. Instantes después, los oficiales de uno y otro bando volvieron a la plaza y entraron en negociaciones. Finalmente, el 10 de noviembre asistieron el capitán comandante del Castillo de San Felipe, don José María Isla, el comisario de guerra 
don Manuel Rodríguez y el síndico procurador de este pueblo don Martín Aramburu, comisionados en representación del comandante general del expresado castillo don Manuel de Carrera y Colina. Anunciaron su misión en "beneficio de la humanidad" y en aras de "evitar la efusión de sangre y poner término de un modo honroso a las aflicciones y padecimientos".

Sobre la base de una propuesta presentada por estos emisarios españoles, se firmó un extenso documento de 26 puntos. En poco más de la mitad del articulado el general Páez dio su aquiescencia sin ningún tipo de reparo, lo cual era un indicativo del consenso que había primado en esta negociación.

En el primer punto se fijó el protocolo que debía seguirse al momento de la evacuación de la plaza por parte de las tropas españolas:

Llegado el caso de que la guarnición de esta fortaleza deba salir de ella, que será según adelante se expresará, lo verificará con la bandera desplegada, tambor batiente, dos piezas de campaña con veinticinco disparos cada una y mechas encendidas, llevando los señores jefes y oficiales sus armas y equipajes, y la tropa su fusil, mochilas, correajes, sesenta cartuchos y dos piezas de chispa por plaza, debiendo a este acto corresponder las tropas de Colombia con los honores acostumbrados de la guerra. ${ }^{54}$

Asimismo, los empleados y comisionados de todos los ramos saldrían con sus familias, armas, equipajes y sirvientes. Se dejó en claro que ningún militar ni empleado podía ser considerado como prisionero de guerra y por tanto, quedaba en libertad de volver a empuñar las armas. Sobre este punto la única observación del general republicano era que los jefes y oficiales podían llevar sus espadas, mas no sus armas y municiones. Ninguno podía salir de la fortaleza hasta tanto no estuviesen disponibles los buques. El pabellón español sólo podía bajarse cuando hubiese evacuado el último de estos hombres.

Tanto empleados como militares debían ser conducidos en buques republicanos con destino a la isla de Cuba a excepción de aquellos de la milicia nacional local que quisieran trasladarse a colonias extranjeras, para lo cual el gobierno republicano también les auxiliaría en el periplo. Sin embargo, los que en su momento se negaran a abordar cuando estuviesen disponibles los buques, debían después efectuar el viaje por su propia cuenta. Antes de la operación de embarque, debía hacerse entrega formal a los comisionados republicanos de todo cuanto existiera en el castillo en el estado en que se encontrara. 
Se propuso preliminarmente que sólo dos horas después de haber zarpado las embarcaciones que transportaban la guarnición, los buques armados republicanos podían entrar al puerto al tiempo que las tropas vencedoras quedaban habilitadas para ocupar el castillo. Sobre este asunto, el general Páez intervino aclarando que las tropas podían ingresar excepcionalmente antes de las dos horas en caso de que existiese amenaza de ataque por parte de alguna escuadra, circunstancia en la cual los oficiales republicanos al mando del castillo izarían una bandera blanca para evitar la violación de estos tratados.

Otra discusión se dio en torno al artículo $13^{\circ}$. Allí los comisionados españoles propusieron que, si alguno de los militares o empleados quisieran permanecer en territorio venezolano, no serían molestados por ello y antes bien, se les brindarían los fueros y prerrogativas que regían para el resto de ciudadanos, ya fuera conservando sus empleos o confiriéndoles pasaportes para que se domiciliaran en el sito de su preferencia. El general en jefe sitiador limitó esta posibilidad únicamente a los empleos de los militares y en todo caso debían respetar las leyes de la República y así obtendrían la garantía de que sus vidas y sus bienes serían respetados. Por otro lado, se dispuso el desarme y devolución a sus dueños de los buques menores particulares fletados por los españoles, incluyendo la flechera Puerteña.

Los artículos 15 y 17 versaron sobre el destino y derechos de la población civil. Infructuosa fue la aspiración de los negociadores españoles en procurar que las viudas, huérfanos o inválidos que, al momento disfrutaban del montepío militar ${ }^{55}$ o cualquier otra pensión del erario español de esta plaza, se les proporcionara asistencia temporal por parte del gobierno republicano hasta el momento en que fueran embarcados a dominio español. La explicación ofrecida por los negociadores del bando victorioso era que no podían comprometerse más allá de brindarles el transporte y los víveres indispensables para el viaje y las raciones mientras se embarcaban.

Se acordó igualmente que a los vecinos y demás habitantes de esta plaza se les respetaran sus vidas y sus bienes, sin importar cuáles fueran sus opiniones políticas, sin impedir su salida y sin prohibirles disponer de sus propiedades aunque los negociadores republicanos fijaron una excepción con relación a las propiedades que su gobierno ya hubiese tomado. Esta medida cobijaba a aquellos ausentes interesados en retornar a la plaza, así como también a los emigrados que por motivo de sus empleos o cualquier otra causa se les hubiese obligado a permanecer en este punto teniendo sus acti-

55 Fondos oficiales creados para facilitarles auxilio en la vejez y enfermedades de los militares o para pensionar a sus viudas o huérfanos. 
vos fuera de esta jurisdicción. Estas disposiciones entrarían en vigencia siempre y cuando no fuesen en contravía de las leyes de la República.

De igual manera, se convino que serían atendidos todos los reclamos de los emigrados republicanos en áreas dominadas por los españoles o en el extranjero interesados en hacer valer sus derechos sobre bienes raíces que hubiesen dejado en esta plaza. Dentro de este beneficio quedaron incluidos los comerciantes, tanto europeos como americanos. Se consideró además que todos los vecinos de los valles colindantes de Borburata, Patanemo y Morón adquirieran los mismos derechos y consideraciones que a los de esta plaza.

Finalmente, se estipuló que los rendidos en el fuerte Mirador de Solano quedaban exentos del juramento que hicieron en su capitulación de no volver a tomar las armas contra la República, al igual que el teniente coronel, don Francisco Urribarry.

En materia de transporte marítimo, los españoles propusieron que dentro de los primeros tres meses de suscrita la capitulación todo buque, tanto de guerra como mercante, que entrara al puerto creyendo que éste aún dependía de la nación española, no podía ser molestado; al contrario, sería protegido. Muy poco compresivo se notó al alto oficial republicano con relación a este punto, pues limitó ese rango de tiempo a sólo quince días, después de lo cual la embarcación sería incautada.

Para asegurar el cumplimiento de lo pactado, cada bando se comprometió a entregar a la contraparte los respectivos rehenes. Por parte del gobierno español, fueron designados el capitán José María Isla y el comisionado de guerra, don José María Rodríguez, y del bando republicano fueron nombrados los capitanes Rafael Romero y Ramón Pérez. ${ }^{56}$

El día en que se firmó el acuerdo, apenas se estaban recibiendo en Bogotá —en la oficina del secretario de Guerra y del vicepresidente Santandercopias del intenso cruce epistolar entre las autoridades de la plaza y las fuerzas sitiadoras en los días previos. Al leer dichos documentos se percataron de que habían sido fallidos tantos intentos de diálogo, así Briceño y Santander coincidieron en que era razonable suspender las intimaciones mientras no se estrechara el bloqueo, para lo cual de inmediato se ordenó aumentar la

56 Páez, Autobiografía, tomo I, pp. 237-242; Archivo del General José Antonio Páez, tomo segundo, pp. 260-265. Esta capitulación fue publicada en la prensa venezolana, véase El Iris de Venezuela, núm. 97, Caracas, por Valentín Espinal, noviembre 21 de 1823, pp. 2-3; El Venezolano, núm. 61, Caracas, por José Núñez Cáceres, noviembre 22 de 1823, pp. 1-2. A principios del año siguiente fue publicado el acuerdo en la prensa neogranadina. Gaceta de Colombia, núm. 117, enero 11 de 1824, Bogotá, Imprenta de Espinosa, p. 9. 
escuadra bloqueadora o lanzar algunas bombas o balas que hicieran sentir al enemigo el peligro y la desesperación. ${ }^{57}$

La rendición de esta plaza fue un motivo de satisfacción para los republicanos. El 9 de diciembre, cuando se llevaba a cabo en la ciudad de Bogotá un baile en la casa de Mary English, la viuda del general irlandés James Towers English, líder de la Legión Británica al servicio de la causa republicana, se asomó el mayor Wilthen, ayudante del general venezolano José Antonio Páez, con la grata noticia de la capitulación de Puerto Cabello. Naturalmente, esta buena nueva contribuyó a amplificar la alegría que se respiraba esa noche. ${ }^{58}$

Sin embargo, la firma del acuerdo de rendición suscitó diferentes reacciones. Para el general Páez, uno de los signatarios, la capitulación había sido "generosísima" para los intereses de los españoles. ${ }^{59} \mathrm{Al}$ parecer, el vicepresidente Santander no había quedado muy contento al enterarse del resultado del arreglo que a su juicio era demasiado generoso. Sobre este particular, el general Páez defendió su gestión, pues aseguró haber obrado de buena fe y con sinceridad, de acuerdo al contexto de aquellos momentos y a los recursos disponibles a su alcance. La referida carta enviada por Santander con las instrucciones para tomar el puerto bajo cualquier sacrificio y el ofrecimiento de 30.000 pesos llegó cuando la plaza ya estaba rendida. Como punto a favor de su decisión, Páez arguyó que la operación no le había costado al erario público ni un maravedí, sólo el gasto correspondiente al consumo básico de carne para la tropa y que incluso los prisioneros habían sido conducidos sin ningún costo. ${ }^{60} \mathrm{Al}$ general Bolívar, quien se hallaba en el sur, también le hizo ver las ventajas de haber recuperado la plaza sin dinero, sin raciones y sin marina. ${ }^{61}$

\section{EL TRATO A LOS CAPITULADOS Y SU EMIGRACIÓN}

Ante los rumores de la amenaza de una supuesta expedición española proveniente de la isla de Puerto Rico, el peligro latente de una retaliación realista y el descomunal costo que acarreaba la subsistencia de la tropa capitulada, Páez estimó que era de máxima urgencia despachar a estos militares y, aun-

AGN, Sección República, Fondo Secretaría de Guerra y Marina, tomo 39, ff. 323r, 343r.

Brown, Aventureros, mercenarios y legiones extranjeras en la Independencia de la Gran Colombia, Medellín, Universidad Pedagógica y Tecnológica de Colombia-La Carreta Editores, 2010, p. 231.

Páez, Autobiografía, tomo I, p. 231.

Ibíd., p. 236.

Cortázar, Correspondencia dirigida, vol. X, pp. 140-141.

O’Leary, Memorias del General O'Leary, tomo II, p. 52. 
que en un principio quiso conseguir barcos mercantes, ante la carencia de éstos optó por utilizar buques de guerra.

Tal como lo reportó el nuevo comandante republicano de la plaza, el coronel Francisco Rodríguez del Toro, al atardecer del 15 de noviembre se embarcó la guarnición española y las tropas patriotas ya guarnecían el castillo. Al día siguiente zarpó el convoy que condujo a los viajeros hasta las costas de Cuba. Las embarcaciones empleadas para esta operación fueron las corbetas Boyacá y Urica, el bergantín Pichincha, la goleta americana $L a$ Tártaro y la flechera Picayo.

Al final, hubo que contratar los servicios del capitán de fragata, J. Mactland, a quien en calidad de comandante del convoy se le impartieron una serie de instrucciones para garantizar óptimas condiciones en el traslado de los capitulados hasta el puerto de Santiago de Cuba. Cuando avistara buques de guerra, el capitán debía izar una bandera blanca en el palo de la proa en cada una de las embarcaciones con el fin de que se supiera que iban en comisión de paz y lo mismo debía hacer al aproximarse a tierra: “[...] echando un bote parlamentario con uno de sus oficiales y otro que envíe el general brigadier don Sebastián de la Calzada para que, informando al gobernador de aquella plaza del motivo de su arribada, se desembarque la gente". ${ }^{62}$ Tanto de ida como de regreso debían suspender cualquier hostilidad contra los buques españoles y se instó al referido capitán, a los comandantes de cada nave y a los oficiales republicanos rehenes para que acogieran y brindaran el mejor trato posible a las tropas españolas mientras que con los jefes y oficiales debían procurar un "inviolable respeto".

Existen por lo menos dos testimonios que dan cuenta del tratamiento amistoso y respetuoso recibido por los capitulados. El primero de ellos es el del capitán de la artillería española Faustino Navarro, quien dio fe de que "[...] los enemigos se han conducido con una generosidad superior a la que se puede figurar”. El segundo es el del jefe superior político e intendente, Diego de Alegría, quien de manera enfática hizo el siguiente reconocimiento: "[...] la conducta de los enemigos en aquella terrible invasión ha sido más humana y plausible que lo que debía esperarse de las circunstancias [...] se han salvado dentro de ella cuantos, vista la superioridad, se rindieron al vencedor". 63

El 10 de diciembre arribó a las playas de Puerto Cabello, procedente de Santiago de Cuba, la corbeta nacional Boyacá y el día 16 los bergantines Urica y Pichincha, embarcaciones que venían de cumplir su misión de con- 
ducir a aquella isla a los capitulados. ${ }^{64}$ De esta forma quedaba liberado el último bastión del poder monárquico y una de sus más importantes fortificaciones, con lo cual quedó sellada la independencia de todo el territorio de Venezuela aunque siguieron algunas escaramuzas por parte de las guerrillas realistas. ${ }^{65}$

Años más tarde, en el juicio que se le siguió al general Calzada y al funcionario Diego de Alegría por la rendición de la plaza, estos hombres salieron librados de toda culpa tras poner de presente la crítica situación en que estaba la guarnición en momentos en que sólo contaban con 300 hombres para defenderse al interior de la plaza y con un número creciente de más de 40 desertores. Según arguyeron, haberse rendido hasta el agotamiento total de los recursos, había conllevado a un escenario desprovisto de posibilidades reales de exigir condiciones y ventajas tanto para la guarnición como para el vecindario. ${ }^{66}$

Entre tanto, el gobierno republicano a través de un decreto dictado por el vicepresidente Santander el 7 de diciembre se aseguró de reconocer el mérito a los que participaron en el ataque y ocupación a esta plaza, confiriéndoles a los oficiales y tropa una medalla honorífica, garantizando los ascensos militares de rigor y asegurando pensión para las viudas de los sacrificados en esa acción.

\section{A MANERA DE COROLARIO}

Las capitulaciones firmadas en Puerto Cabello fueron la culminación de una serie de esfuerzos conciliadores de esta misma clase que se suscribieron en territorio venezolano y en otras ciudades de la Nueva Granada y las provincias del Sur, como fue el caso de La Guaira, Cumaná, Maracaibo, Santa Marta, Cartagena, Pasto ${ }^{67}$ y Quito. Esta vía pacífica fue, en términos reales, una opción sensata de las partes en la fase final de una guerra larga y cruenta.

Vale mencionar de manera especial la insistencia del bando republicano en cabeza del general José Antonio Páez en buscar la vía negociada en momentos en que no podía bajar la guardia sobre los territorios ya conquista-

Archivo del General José Antonio Páez, tomo segundo, p. 310.

65 Baralt, Díaz, Resumen de la Historia de Venezuela, Cabimas, UNERMB, 2016, tomo III, p. 184.

66 Fernández, Últimos reductos, p. 135.

67 Véase Pita, "Las Capitulaciones en las guerras de Independencia de Colombia: aproximaciones a un estudio comparativo para los casos de Cartagena y Pasto", El Taller de la Historia, núm. 9, Cartagena, Universidad de Cartagena, 2017, pp. 58-79. 
dos. Una conjugación de habilidades estratégicas al momento de negociar lograron convencer a los mandos españoles de lo inútil y costoso que resultaba una confrontación militar de grandes magnitudes. El resultado satisfactorio salta a la vista por cuanto el saldo total de la toma de la ciudad fue de no más de 170 víctimas.

En síntesis, Puerto Cabello sería la última ocasión en que se pondría en práctica este componente de conciliación en todo el territorio de la República de Colombia. Ante los fallidos intentos por firmar un tratado de paz entre España y sus antiguos dominios americanos, fueron valiosas las vías alternativas parciales que, como los armisticios, las capitulaciones y las normas de regularización, se constituyeron en mecanismos tendientes a morigerar los impactos de la guerra. Serían, en últimas, precedentes innovadores surgidos en territorio americano con aportes significativos al desarrollo del derecho internacional humanitario.

Después de estos sucesos, muchos de los militares que participaron en la recuperación de Puerto Cabello fueron movilizados por orden de Bolívar a tierras del Perú en donde tendría lugar en 1824 un nuevo episodio glorioso de la Campaña Libertadora de estas naciones suramericanas.

En los años siguientes, apaciguado ya el furor de la guerra, emergió una gran cantidad de solicitudes de militares en busca de ascensos, reconocimiento de salarios atrasados, licencias absolutas o, en otros casos, simplemente algún permiso para retornar así fuere temporalmente al seno de sus familias luego de varios años de lucha armada a favor de una Patria libre y soberana. Entre tanto, diversos y complejos serían los caminos de reintegración de los realistas a la vida republicana, procesos en los que se dieron nuevos mensajes de inclusión y de reconocimiento de la "otredad". ${ }^{68}$

La liberación de Coro, Maracaibo y Puerto Cabello, ciudades que por mucho tiempo vivieron alejadas de la causa emancipadora, permitiría consolidar el proyecto republicano, lo cual implicaba acciones inmediatas, como por ejemplo la publicación de la Constitución de Colombia en estos territorios independizados, a lo que se sumaron otros dispositivos como la implementación del proyecto educativo liberal y la prensa, todo en torno a suscitar consensos y unanimidad en el proceso de formación de nación ${ }^{69}$ en medio de un ambiente de tensión ante el temor latente de una reacción política antirrepublicana promovida por tendencias conservadoras. ${ }^{70}$

La Independencia de Venezuela, p. 561, 620.

69 Hébrard, Venezuela independiente: una nación a través del discurso (1808-1830), Madrid, Universidad Católica Iberoamericana, 2012, pp. 339-348.

70 Carrera, La disputa de la Independencia de Venezuela: auge, tregua y reanudación 18151821, Caracas, Fundación Rómulo Betancourt, 2012, pp. 20-31. 
Hacia 1827 entró en crisis la unión de los territorios ungidos bajo el nombre de República de Colombia y, pese a los intentos por salvarla y ante la muerte del Libertador Simón Bolívar, finalmente al cabo de tres años terminó disolviéndose aquella asociación, después de lo cual el general José Antonio Páez declaró la autonomía de Venezuela que inició su camino como nación libre y soberana. España, entre tanto, se mantuvo reacia a aceptar la independencia de Venezuela y no fue sino hasta después del fallecimiento de Fernando VII ${ }^{71}$ que se dieron los primeros avances conciliadores hasta que finalmente en 1845 se oficializó ese reconocimiento.

\section{BibLIOGRAFÍA}

Academia Colombiana de Historia, Fondo Archivo del General Miguel de la Torre, tomo I, pp. 112-116.

Acuerdos del Consejo de Gobierno de Gobierno de la República de Colombia, 18211824, Bogotá, Biblioteca de la Presidencia de la República, 1988, tomo I.

Alfaro Pareja, Francisco, La Independencia de Venezuela relatada en clave de paz. Las regulaciones pacíficas entre patriotas y realistas (1810-1846), Castellón, Universitat Jaume, 2013.

Archivo del General José Antonio Páez, 1818-1820, Bogotá, Editorial “El Gráfico”, 1939, tomo segundo.

Archivo General de la Nación (AGN), Bogotá-Colombia, Sección República, Fondo Secretaría de Guerra y Marina.

Baralt, Rafael María y Ramón Díaz, Resumen de la historia de Venezuela, Cabimas, UNERMB, 2016.

Becker, Jerónimo, La Independencia de América, Madrid, Establecimiento Tipográfico de Jaime Ratés, 1922.

Boletín de la Academia Nacional de la Historia, año I, tomo I, núm. 2, Caracas, Academia Nacional de la Historia, junio 30 de 1912, pp. 123-125.

Brown, Matthew, Aventureros, mercenarios y legiones extranjeras en la Independencia de la Gran Colombia, Medellín, Universidad Pedagógica y Tecnológica de Colombia-La Carreta Editores, 2010.

Cabanellas de Torres, Guillermo, Diccionario militar, aeronáutico, naval y terrestre, Buenos Aires, Bibliográfica Omeba, 1963, tomo I.

Carrera Damas, Germán, La disputa de la Independencia de Venezuela: auge, tregua y reanudación 1815-1821, Caracas, Fundación Rómulo Betancourt, 2012.

71 Becker, La Independencia de América, Madrid, Establecimiento Tipográfico de Jaime Ratés, 1922, p. 117. 
Colección de documentos relativos a la vida pública del Libertador, Caracas, Imprenta de Devismes Hermanos, 1826, tomo tercero.

Constitución de la República de Colombia, impresa en la Villa del Rosario, Filadelfia, Juan F. Hurtel, Impresor, 1822.

Correo del Orinoco, Angostura, Impreso por Tomás Bradshaw, diciembre 30 de 1820.

Cortázar, Roberto (comp.), Correspondencia dirigida al General Santander, Bogotá, Academia Colombiana de Historia, 1969, vol. X, XII.

Documentos relativos al bloqueo de Puerto Cabello por los patriotas después de la batalla triunfal de Carabobo, Boletín de la Academia Nacional de la Historia, año I, tomo I, núm. 2, Caracas, Academia Nacional de la Historia, junio 30 de 1912, pp. 117-126.

Earle, Rebecca, España y la Independencia de Colombia, 1810-1825, Bogotá, Universidad de Los Andes, 2014. DOI: 10.7440/2014.16

El Iris de Venezuela, Caracas, por Valentín Espinal, 1823.

El Venezolano, Caracas, Por José Núñez Cáceres, 1823.

Fernández, Delfina, Últimos reductos españoles en América, Madrid, Colecciones Mapfre, 1992.

Franco, José L. (comp.), Documentos para la historia de Venezuela existentes en el Archivo Nacional de Cuba, La Habana, Archivo Nacional de Cuba, 1960.

Gaceta de Colombia, Bogotá, Imprenta de Espinosa, 1823-1824.

Gaceta de Caracas, Caracas, Imprenta de J. Gutiérrez, 1820-1821.

Giménez Silva, Floralgia, La Independencia ante las Cancillerías europeas, Caracas, Academia Nacional de la Historia.

González, Asdrúbal, La guerra de Independencia en Puerto Cabello, Caracas, Ediciones del Congreso de la República, 1988.

Hébrard, Véronique, Venezuela independiente: una nación a través del discurso (1808-1830), Madrid, Universidad Católica Iberoamericana, 2012. DOI: $10.31819 / 9783954870011$

Izard, Miguel, El miedo a la Revolución. La lucha por la libertad en Venezuela (1777-1830), Madrid, Editorial Tecnos, 1979.

O’Leary, Simón B., Memorias del General O’Leary, Caracas, Imprenta de la Gaceta Oficial, 1983, tomos III, XIX.

Páez, José Antonio, Autobiografía, Medellín, Editorial Bedout, 1973, tomo I.

Pérez Jurado, Carlos, "Relación de prisioneros realistas. Datos y hechos para el estudio de la Guerra de Independencia y el Derecho Internacional de Guerra y Humanitario", "Boletín de la Academia Nacional de la Historia”, tomo LXXXII, núm. 325, Caracas, Academia Nacional de la Historia, enero-marzo de 1999, pp. 105-143.

Pita Pico, Roger, "Las Capitulaciones en las guerras de Independencia de Colombia: aproximaciones a un estudio comparativo para los casos de Cartagena y Pas- 
to”, El Taller de la Historia, núm. 9, Cartagena, Universidad de Cartagena, 2017, pp. 58-79. DOI: 10.32997/2382-4794-vol.1-num.9/2017/84

Restrepo, José Manuel, Documentos importantes para la historia de la Revolución de la República de Colombia en la América Meridional, Medellín, Universidad de Antioquia-Universidad Nacional, 2009, CD.

Restrepo, José Manuel, Historia de la Revolución de la República de Colombia, Bogotá, Editorial Besanzon, 1858, tomo III.

Thibaud, Clement, Repúblicas en armas. Los ejércitos bolivarianos en la guerra de Independencia en Colombia y Venezuela, Bogotá, Planeta-IFEA, 2003. DOI: $10.4000 /$ books.ifea.4320

Zapatero, Juan Manuel, Historia de las fortificaciones de Puerto Cabello, Caracas, Banco Central de Venezuela, 1977. 